\title{
A Study of Optimism of Upper Primary Teachers in Relation to Gender, School Type \& Teaching Experience
}

\author{
Dr. Shashi Chaudhary ${ }^{1}$, Prof. Kavita Varma ${ }^{2}$ \\ ${ }^{1}$ Assistant Professor, Faculty of Education, GLA University, Mathura, Uttar Pradesh, India. \\ E-mail: shashi.chaudhary@gla.ac.in \\ ${ }^{2}$ Principal, Faculty of Education, GLA University, Mathura, Uttar Pradesh, India. \\ E-mail: kavita.varma@gla.ac.in
}

Article History: Received: 11 January 2021; Accepted: 27 February 2021; Published online: 5 April 2021

\begin{abstract}
In the present study, Optimism have been studied with reference to the gender, school type and teaching experience of upper primary teachers. In this study male \&female, government\& non-government and teaching experiences of teachers divided into four categories: first category (less than 5 years of teaching experience), second category (5-15 years of teaching experience), third category (16-25 years of teaching experience), fourth category (more than 25 years of teaching experience). The research conducted on total 800 teachers working in Upper primary schools in Mathura and Agra District. Random sampling method was used for data collection. A survey method was used. Self-made questionnaire having 20 questions used for data collection. Overall result of the study found Average in relation to Gender, School Type \& Teaching Experience
\end{abstract}

Keywords: Optimism, Upper Primary Teachers, School Type.

\section{Introduction}

Education is a subject area of an interdisciplinary nature. Many factors affect the process of education. In the teaching process it becomes necessary to know the meaning of optimism. The literal meaning of optimism is "Best of all possible worlds" in this phrase, "the most possible" means the possibility of positive or hope in every situation. Optimism was first defined by psychologist Martin Seligman and his book "Learned Optimism" was published in 1990.

\section{Purpose of the Study}

To study the percentage level of Optimism of upper primary teachers in relation to gender, school type and teaching experience.

\section{Objectives of the Study}

To study the Optimism of upper primary teachers in relation to gender, school type and teaching experience.

\section{Hypothesis of the Study}

There is no difference in between the Optimism of upper primary teachers in relation to gender, school type and teaching experience.

\section{Methodology}

The present study is dealing with the investigation of optimism of 800 Upper Primary school teachers of Mathura and Agra district, in relation to gender, school type and teaching experience. Random sampling method was used for data collection. The researcher has employed survey method. It attempts to describe and interpret practices, processes, trends, effects, attitudes and beliefs etc. of the present phenomenon. Hence, this method has been found to be most suitable for present study.

\section{Variables}

Dependent Variable: Gender, School Type \& Teaching Experience.

Independent Variable: Optimism.

\section{Tool Used}

Self-made questionnaire having 20 questions based on theory of optimism used for data collection. Before using this questionnaire, it was sent to experts for review.

\section{Statistical analysis: Percentage}

\section{Result Analysis and Interpretation}

The level of optimism of teachers is presented in Table 1 as a percentage in relation to gender, school type and teaching experience. 
Table 1. Overall Levels of Optimism of Upper Primary Teachers: in Relation to Gender, School Type and Teaching Experience

\begin{tabular}{|c|c|c|c|c|c|c|c|c|c|c|c|c|c|c|c|c|}
\hline \multirow{4}{*}{$\begin{array}{c}\text { Levels of } \\
\text { Optimism }\end{array}$} & \multicolumn{16}{|c|}{ Teacher number and percentage } \\
\hline & & & & & & Sch & Typ & & & & Teac & ing & xper & nce & & \\
\hline & \multicolumn{2}{|c|}{ Female } & \multicolumn{2}{|c|}{ Male } & & Government & \multicolumn{2}{|c|}{$\begin{array}{c}\text { Non- } \\
\text { Government }\end{array}$} & \multicolumn{2}{|c|}{$\begin{array}{c}\text { Less than } 5 \\
\text { year }\end{array}$} & \multicolumn{2}{|c|}{$\begin{array}{l}5 \& 15 \\
\text { year }\end{array}$} & \multicolumn{2}{|c|}{$\begin{array}{c}16 \& 25 \\
\text { year }\end{array}$} & \multicolumn{2}{|c|}{$\begin{array}{c}\text { More } \\
\text { than } 25 \\
\text { year }\end{array}$} \\
\hline & $\mathrm{N}$ & $\%$ & $\mathrm{~N}$ & $\%$ & $\mathrm{~N}$ & $\%$ & $\mathrm{~N}$ & $\%$ & $\mathrm{~N}$ & $\%$ & $\mathrm{~N}$ & $\%$ & $\mathrm{~N}$ & $\%$ & $\mathrm{~N}$ & $\%$ \\
\hline High & 102 & 26 & 119 & 30 & 113 & 28 & 108 & 27 & 60 & 24 & 132 & 30 & 24 & 24 & 5 & 36 \\
\hline Average & 193 & 48 & 186 & 46 & 191 & 48 & 188 & 47 & 110 & 44 & 208 & 48 & 55 & 54 & 6 & 43 \\
\hline Low & 105 & 26 & 95 & 24 & 96 & 24 & 104 & 26 & 82 & 32 & 93 & 22 & 22 & 22 & 3 & 21 \\
\hline
\end{tabular}

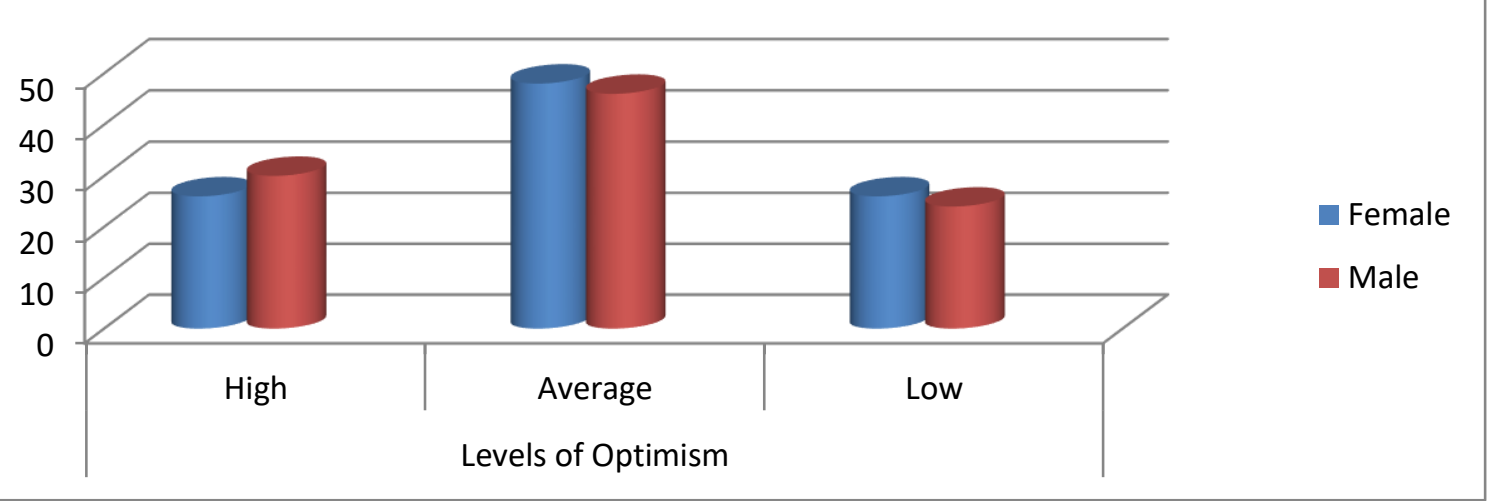

Graph 1. Shows Comparison in Male and Female Teachers at Different Levels of Optimism

Graph-1 depicts 26\%, $48 \%$ and $26 \%$ female teachers have been found at the high, average and low levels of optimism respectively. Similarly, $30 \%, 46 \%$ and $24 \%$ male teachers have been found at the high, average and low levels of optimism respectively.

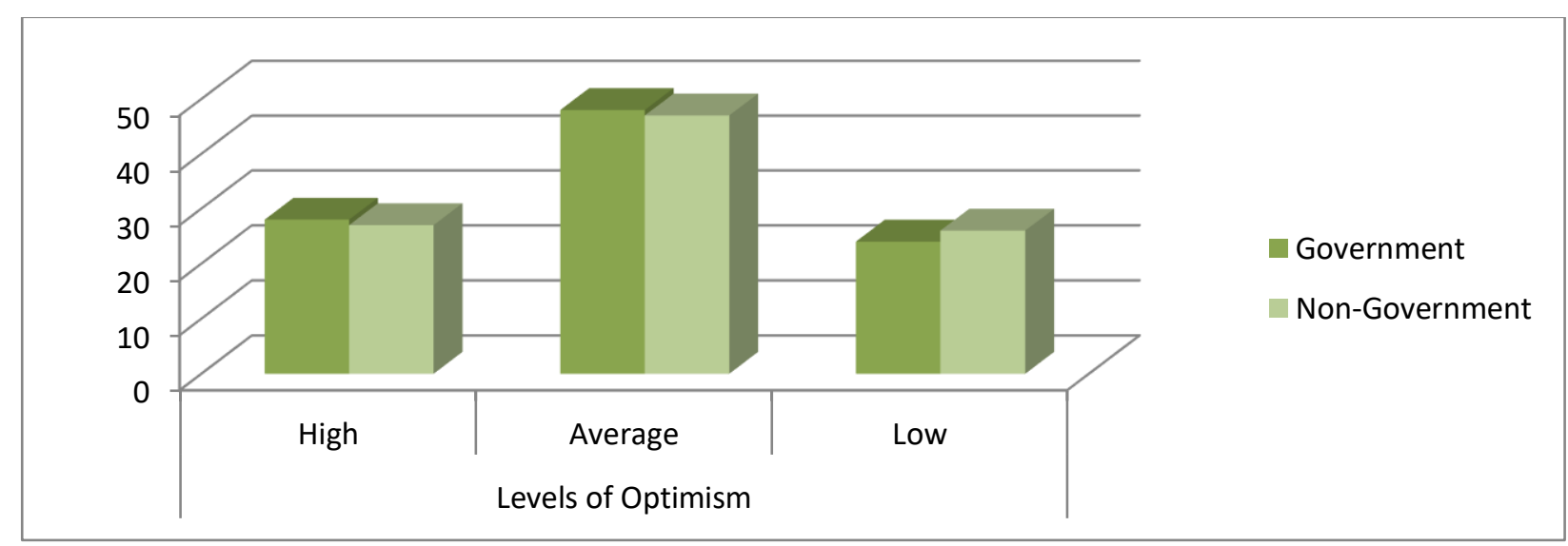

Graph 2. Shows a Comparison in Teachers at Different Levels of Optimism in Relation to School Type

Graph-2 depicts that $28 \%, 48 \%$ and $24 \%$ government teachers have been found at the high, average and low levels of optimism respectively. Similarly, 27\%, $47 \%$ and $26 \%$ non-government teachers have been found at the high, average and low levels of optimism respectively. 


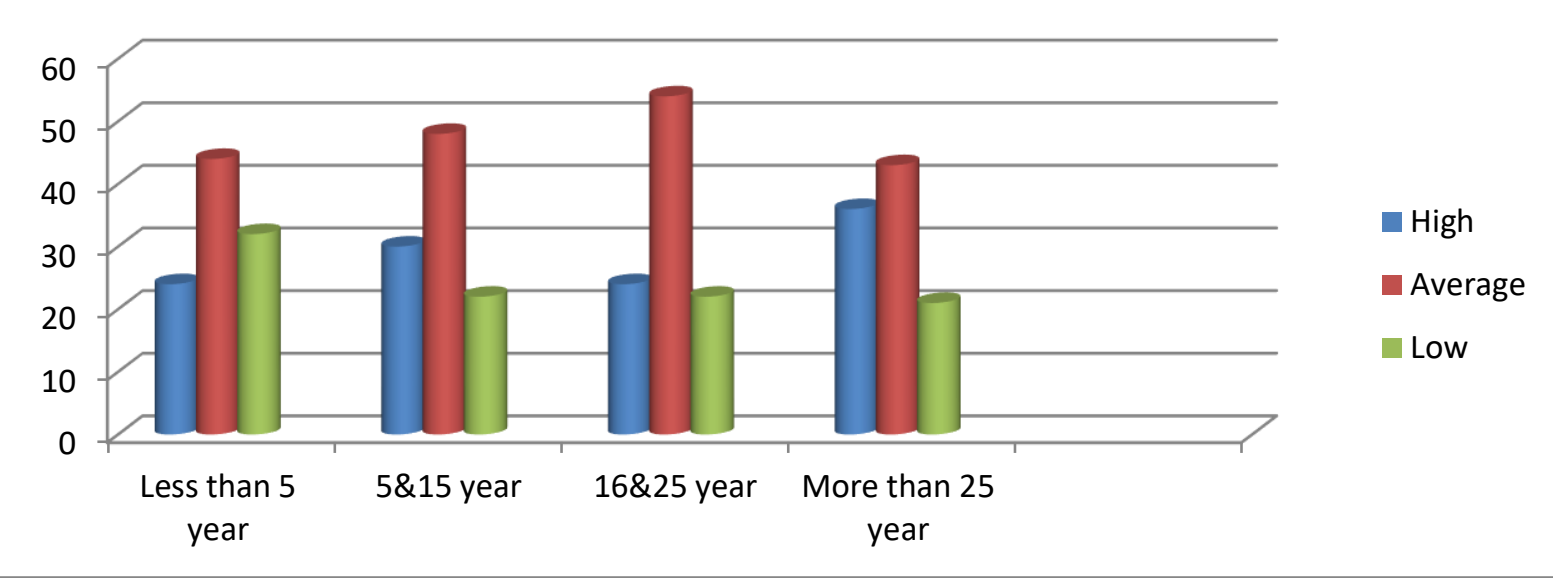

Graph 3. Shows a Comparison of Teachers at different Levels of Optimism in Relation to Teaching Experience

Graph-3 depicts that 24\%, $44 \%$ and 32\% Teachers of first category teaching experience (less than 5 years) have been found respectively at high, average and low level of optimism. $30 \%, 48 \%$ and $22 \%$ teachers of second category teaching experience ( $5-15$ years) have been found respectively at high, average and low level of optimism. 24\%, 54\% and 22\% teachers of third category teaching experience (16-25 years) have been found respectively at high, average and low level of optimism.36\%, $43 \%$ and $21 \%$ Teachers of fourth category teaching experience (more than 25 years) have been found respectively at high, average and low level of optimism.

\section{Conclusive}

Therefore, hypothesis "There is no difference in between the Optimism of Upper Primary teachers in relation to gender, school type and teaching experience " is not accepted. Thus the level of optimism in teachers has been found to be different. Thus it is visible that the highest teacher percentage has been found at average level of optimism, ( $48 \%$ female and $46 \%$ male). There is not much difference in the percentage of female and male teachers at low and high levels. Thus it is visible that the highest teacher percentage has been found at average level of optimism, ( $48 \%$ government and $47 \%$ non-government). There is not much difference in the percentage of government and non-government teachers at low and high levels. Thus, it is visible that the percentage of first, second, third and fourth categories teachers of teaching experience at the average level of optimism is $44 \%, 48 \%$, $54 \%$ and $43 \%$ respectively which is very higher. The percentage of teachers of all categories of teaching experience at high level is found to be lower than average level but higher than low level. There is not much difference in the low levels of optimism of percentage of teachers of all categories of teaching experience and the least percentage of teacher of three categories of teaching experience is found at low level.

\section{References}

5. Ai, A.L., Evans-Campbell, T., Santangelo, L.K., \& Cascio, T. (2006). The traumatic impact of the September 11, 2001, terrorist attacks and the potential protection of optimism. Journal of interpersonal violence, 21(5), 689-700.

6. Avey, J.B., Luthans, F., \& Jensen, S.M. (2009). Psychological capital: A positive resource for combating employee stress and turnover. Human resource management, 48(5), 677-693.

7. Akhtar, S., Ghayas, S., \& Adil, A. (2013). Self-efficacy and optimism as predictors of organizational commitment among bank employees. International Journal of Research Studies in Psychology, 2(2), $33-42$.

8. Bhatnagar, R.P. (2008). Readings in Methodology of Research in Education. R. Lall Book Depot, Meerut.

9. Creswell, J.W. (2011). Educational Research: Planning Conducting, and Evaluating Quantitative and Qualitative Research. PHI Learning Private Limited, New Delhi.

10. Gupta, S.P. (2002). Modern Measurement and Evaluation. Sharda Book Building, Allahabad. 